\section{Strategies for Weed Suppression and Improving Soil Fertility during Transition to Organic Vegetable Production}

\author{
Stephanie Wedryk ${ }^{1,4}$, Joel Felix ${ }^{2}$, Doug Doohan ${ }^{3}$, \\ and John Cardina ${ }^{3}$
}

AdDitional INDEX wORDs. tomato, Solanum lycopersicum, potato, Solanum tuberosum, smother crop, prairie

SUMMARY. Farmers view weed management and the risk of lower yields as barriers to transition from conventional to organic agriculture. The 3 years of transition before organic certification can be used to implement strategies to suppress weeds and improve soil fertility. The objective of this research was to evaluate the effects of five organic transition strategies on soil quality, weed suppression, and yield of tomato (Solanum lycopersicum) and potato (Solanum tuberosum) in the first year of organic production. The transition strategies included a tilled fallow, nontreated weedy, high diversity prairie mixture, smother crops, and vegetable rotation. Subplots with and without compost application were also included. Transition strategies affected weed density and biomass in the first organic year with the prairie strategy being the most suppressive of monocotyledonous weeds before potato. Compost application increased plant available nutrients and soil organic matter (OM). The quantity of plant available phosphorus was greatest in the fallow transition strategy $\left(55 \mathrm{mg} \cdot \mathrm{kg}^{-1}\right)$ when compost was applied, while percent soil OM was highest in the prairie (3.2\%) and nontreated (3.1\%) strategies in comparison with the other strategies. Compost application increased yields of potato and tomato with transition strategy affecting the number and weight of cull potato tubers. The selection of transition strategies before conversion to organic agriculture affected weed pressure, soil quality, and crop production in the first certified organic year.

$\mathrm{E}$ nvironmental quality and public health concerns about the use of chemicals in conventional agriculture have driven a large increase in demand for organic food (Dorais, 2007). Acreage of certified organic farm land in vegetable production in the United States has increased by $62 \%$ between 1995 and 2008 [U.S. Department of Agriculture (USDA), 2010]. Although growers have obtained higher prices

Salaries and research support were provided by State and Federal Funds appropriated to the Ohio Agriculture Research and Development Center, The Ohio State University. Manuscript No. HCS-12-04.

We thank Lynn Ault, K. Gregory Smith, Jennifer Moyseenko, Catherine P. Herms, Sonia Walker and staff of the Ohio Agricultural Research and Development Center and Weed Ecology Lab in Wooster, $\mathrm{OH}$ for their assistance and expertise and James VanLeeuwen for providing critical knowledge of tef management.

${ }^{1}$ Department of Horticulture and Crop Science, The Ohio State University, 2021 Coffey Road, Columbus, $\mathrm{OH} 43210$

${ }^{2}$ Crop and Soil Science Department, Oregon State University, Malheur Experiment Station, 595 Onion Avenue, Ontario, OR 97914

${ }^{3}$ Department of Horticulture and Crop Science, The Ohio State University, Ohio Agricultural Research and Development Center, 1680 Madison Avenue, Wooster, OH 44691

${ }^{4}$ Corresponding author. E-mail wedryk.1@osu.edu. and seen growth in demand for organic products, many farmers are reluctant to convert to organic agriculture because of perceived risks of lower yields and challenges in managing pests (Beveridge and Naylor, 1999; Hanson et al., 2004; Oberholtzer et al., 2005). Weed control, especially management of perennial weeds, is often cited by farmers as a barrier to transition to organic production (Turner et al., 2007; Verschwele and Häusler, 2004). During the mandated 3 -year-transition period from conventional to organic agriculture in the United States, many farmers adopt biological, cultural, and mechanical techniques that aid in building soil fertility and suppressing weeds with the potential to enhance yields in the first organic year (Hanson et al., 2004).

Compost applications during transition to organic vegetable production and after transition have helped to improve soil OM and microbial biomass, alter nematode communities, and increase the concentration of plant available macro- and micronutrients (Baysal et al., 2008; Briar et al., 2011; Martini et al., 2004; Smukler et al., 2008). Improvements in soil quality as a result of organic material addition are often associated with improvements in vegetable yield (Briar et al., 2011; Russo and Taylor, 2006). However, the cropping system used during transition can interact with compost application to affect yield and soil fertility. Intensive vegetable production in high tunnels resulted in higher tomato yields in the first organic year than other transition strategies including tilled fallow, hay, and field vegetable production (Briar et al., 2011). Weed suppression and grain yields in the first certified organic year can be affected by the species of cover crop used during 3 years of transition (Smith et al., 2011). Transitional strategies of different agronomic crop rotations affected weed seedbank density and soil aggregate size in the first year of certified organic production (Corbin et al., 2010). Weed populations and soil fertility during organic transition are affected by transition cropping systems and can subsequently affect yield in the first certified organic year. Multifunction cropping systems can be used to address multiple management issues that constrain production, but the relative importance of individual issues in affecting yields is not clearly understood (Larkin et al., 2011). Previous research on organic

\begin{tabular}{llll}
\hline $\begin{array}{l}\text { Units } \\
\text { To convert U.S. to SI, } \\
\text { multiply by }\end{array}$ & U.S. unit & SI unit & $\begin{array}{l}\text { To convert SI to U.S., } \\
\text { multiply by }\end{array}$ \\
\hline 0.4047 & $\mathrm{acre}(\mathrm{s})$ & $\mathrm{ha}$ & 2.4711 \\
29.5735 & $\mathrm{fl} \mathrm{oz}$ & $\mathrm{mL}$ & 0.0338 \\
0.3048 & $\mathrm{ft}$ & $\mathrm{m}$ & 3.2808 \\
0.0929 & $\mathrm{ft}^{2}$ & $\mathrm{~m}^{2}$ & 10.7639 \\
2.54 & inch(es) & $\mathrm{cm}$ & 0.3937 \\
1.1209 & $\mathrm{lb} / \mathrm{acre}$ & $\mathrm{kg} \cdot \mathrm{ha}^{-1}$ & 0.8922 \\
28.3495 & $\mathrm{oz}$ & $\mathrm{g}$ & 0.0353 \\
305.1517 & $\mathrm{oz} / \mathrm{ft}^{2}$ & $\mathrm{~g} \cdot \mathrm{m}^{-2}$ & 0.0033 \\
1 & $\mathrm{ppm}$ & $\mathrm{mg} \cdot \mathrm{kg}^{-1}$ & 1 \\
2.2417 & ton $/ \mathrm{acre}$ & $\mathrm{Mg} \cdot \mathrm{ha}^{-1}$ & 0.4461 \\
$\left({ }^{\circ} \mathrm{F}-32\right) \div 1.8$ & ${ }^{\circ} \mathrm{F}$ & ${ }^{\circ} \mathrm{C}$ & $\left(1.8 \times{ }^{\circ} \mathrm{C}\right)+32$ \\
& & & \\
\end{tabular}


transition strategies has not simultaneously compared the differences in weed suppression, soil fertility, and organic vegetable production in different systems.

This research was conducted to assess the effectiveness of strategies for simultaneously suppressing weeds, enhancing soil fertility, and improving organic vegetable yields during transition to organic agriculture in Ohio. Five transition strategies were implemented to mirror current farmer and researcher practices such as growing vegetables, tilled fallow, and mowing, with novel strategies such as prairie biomass production and summer annual smother crops. The objective of this study was to evaluate soil quality, response of annual and perennial weed populations, and compare yields in tomato and potato production in the first certifiable organic year after 3 years of transition strategies and compost application. We hypothesize that weed competition and soil quality will be affected by 3 years of transition strategy and compost application. Further, we hypothesize that transition strategy and compost application as well as resulting weed populations and soil fertility will affect tomato and potato yields.

\section{Materials and methods}

STUDY SITE. Field experiments were conducted at The Ohio State University Schaffter Farm near Wooster, $\mathrm{OH}$, from 2007 to 2010. The soil type at the site (lat. $40^{\circ} 45^{\prime} \mathrm{N}$, long. $81^{\circ} 54^{\prime} \mathrm{W}$ ) was classified as a fine, mixed, Typic Fragiaqualf (Luvisols) of the Wooster series, a moderately well-drained silt loam with $\mathrm{pH}$ of $6.8,2.2 \% \mathrm{OM}$, and available phosphorus $(\mathrm{P})$ and potassium $(\mathrm{K})$ of 26.8 and $116.7 \mathrm{mg} \cdot \mathrm{kg}^{-1}$ soil, respectively. The site was a 3-year-old conventionally managed red clover (Trifolium pratense) pasture before experiment initiation. The experiment was managed without pesticides or chemical fertilizers to represent the transition from conventional to organic agriculture.

EXPERIMENTAL DESIGN. Five organic transition strategies were established in 2007 and continued through 2009 to represent the 3 years of organic transition. The experimental setup was a split-plot design with six replications. Main plot factors were organic transition strategy and subplot factors were compost application.
Main plot dimensions were $12 \times 15 \mathrm{~m}$. Experimental plots were maintained with the same treatment each year. The five organic transition strategies included 1) tilled fallow, 2) nontreated, 3 ) high-diversity tallgrass prairie, 4) vegetable, and 5 ) smother crops.

FALLOW AND NONTREATED TRANSITION STRATEgIES. The tilled fallow treatment was cultivated three to four times each growing season when present canada thistle (Cirsium arvense) populations reached the green bud stage. In the nontreated strategy, weeds were mowed four times per growing season to prevent annual weeds from setting seed.

Prairie transition strategy. The prairie mixture was broadcast seeded at a rate of $1.69 \mathrm{~g} \cdot \mathrm{m}^{-2}$ on 12 June 2007, and cultimulched to ensure seed and soil contact. Straw was subsequently laid on the plots to encourage prairie seed germination. Species included in the mix were one $\mathrm{C}_{3}$ grass [canada wildrye (Elymus canadensis) ] at $0.11 \mathrm{~g} \cdot \mathrm{m}^{-2}$, two $\mathrm{C}_{4}$ grasses [big bluestem (Andropogon gerardii) at $0.11 \mathrm{~g} \cdot \mathrm{m}^{-2}$ and indian grass (Sorghastrum nutans) at $\left.0.10 \mathrm{~g} \cdot \mathrm{m}^{-2}\right]$, one spiderwort [ohio spiderwort (Tradescantia obiensis) at $\left.0.11 \mathrm{~g} \cdot \mathrm{m}^{-2}\right]$, two legumes [wild senna (Senna bebecarpa) at $0.099 \mathrm{~g} \cdot \mathrm{m}^{-2}$ and round bushclover (Lespedeza capitata) at $0.095 \mathrm{~g} \cdot \mathrm{m}^{-2}$ ], and 10 forbs [grayheaded coneflower (Ratibida pinnata) at $0.10 \mathrm{~g} \cdot \mathrm{m}^{-2}$, biennial gaura (Gaura biennis) at $0.10 \mathrm{~g} \cdot \mathrm{m}^{-2}$, stiff goldenrod (Solidago rigida) at $0.11 \mathrm{~g} \cdot \mathrm{m}^{-2}$, tall coneflower (Rudbeckia laciniata) at $0.11 \mathrm{~g} \cdot \mathrm{m}^{-2}$, smooth penstemon (Penstemon digitalis) at $0.11 \mathrm{~g} \cdot \mathrm{m}^{-2}$, false sunflower (Helianthus helianthoides) at $0.10 \mathrm{~g} \cdot \mathrm{m}^{-2}$, brown-eyed susan ( $R u d$ beckia triloba) at $0.098 \mathrm{~g} \cdot \mathrm{m}^{-2}$, tall coreopsis (Coreopsis tripteris) at 0.13 $\mathrm{g} \cdot \mathrm{m}^{-2}$, lowrie's aster (Aster lowrieanus) at $0.10 \mathrm{~g} \cdot \mathrm{m}^{-2}$, and new england aster (Aster novae-anglia) at $0.11 \mathrm{~g} \cdot \mathrm{m}^{-2}$ (Stucker Meadow, Holmesville, OH)]. There was no additional management of the prairie transition strategy in 2008 or 2009.

VEGETABLE TRANSITION STRATEGY. The vegetable transition strategy was seeded with 'Gardensoy' edamame soybean (Glycine max) (Rupp Seeds, Wauseon, OH) on 7 June 2007 at a rate of 296,000 seeds/ha in 30inch rows at a depth of 1 inch using a four-row planter (John Deere 7000 series; Deere \& Company, Moline,
IL). Cultivation was used for interrow weed control when weeds were $\approx 4 \mathrm{~cm}$ tall. Soybean was harvested 15 Sept. 2007. In 2008, 'North Star', 'Green Towers', 'New Red Fire', and 'Tropicana' lettuce (Lactuca sativa) seeds (K.W. Zeller and Sons, Hartville, $\mathrm{OH}$ ) were germinated in 200-cell flats under greenhouse conditions on 14 April and 28 April and hand transplanted on 22 May and 12 June into black landscape cloth. Black landscape cloth was installed flat on the ground on 21 May 2008 before transplanting lettuce. Interrow and intrarow spacing was $1 \mathrm{ft}$, respectively. Brassica crops ['Super Red 80' red cabbage (Brassica oleracea var. capitata f. rubra), 'Diplomat' broccoli ( $B$. oleracea var. botrytis), 'Oliver' brussels sprouts ( $B$. oleracea var. gemmifera), and 'Winterbor' kale ( $B$. oleracea var. viridis) (Johnny's Selected Seeds, Winslow, ME)] were seeded 200-cell flats using potting medium (Pro-Mix; Premier Tech Horticulture, Quakertown, PA) in the greenhouse on 13 May, 27 May, and 12 June 2008. Seedlings were hand transplanted on 1 July, 21 July, and 4 Aug. into black landscape cloth after lettuce harvest. Interrow spacing was $2 \mathrm{ft}$ for all species and intrarow spacing for cabbage, kale, and brussels sprouts was $1 \mathrm{ft}$ and $2 \mathrm{ft}$ for broccoli. Black landscape cloth was used for weed control and vegetables were drip-irrigated throughout the season as necessary. In 2009, 'Gardensoy' edamame soybeans were seeded on 5 June, harvested 23 Sept., and followed the same management protocol as 2007.

SMOTHER CROP TRANSITION STRATEGY. The smother crop strategy was seeded using a Great Plains NoTill Drill (Great Plains Manufacturing, Salina, KS) on 25 May 2007 with a 1:1 mixture of 'Royal' oat (Avena sativa) and 'Packer' field pea (Pisum sativum) mixture (La Crosse Forage and Turf Seed, La Crosse, WI) at 108 $\mathrm{kg} \cdot \mathrm{ha}^{-1}$ at a depth of $\mathrm{l}$ inch and harvested on 12 July 2007. In 2008, a split-split plot design was used in the smother crop transition strategy. Main plot factor was organic transition strategy, subplot factor was compost application, and sub-subplot factor was smother crop species. The first smother crop species was 'VA-Tl' tef (Eragrostis tef) (James VanLeeuwen, Halsey, OR) broadcast seeded at $27 \mathrm{~kg} \cdot \mathrm{ha}^{-1}$ and cultipacked to ensure 
soil and seed contact on 29 May 2008. The second smother crop species was 'Special Effort' sorghum-sudangrass (Sorghum bicolor $\times$ Sorghum sudanese) (Production Plus Quality Seed, Plainview, TX) drill-seeded using a Great Plains No-Till Drill at $25 \mathrm{~kg} \cdot \mathrm{ha}^{-1}$ on 29 May 2008. Tef and sorghumsudangrass were mowed in Oct. 2008 and residues were tilled under the following spring. In 2009, 'Special Effort' sorghum-sudangrass was planted 24 May with the same management as the previous year.

Compost. Compost was applied as a subplot factor each year of organic transition. The treatment levels were no compost and composted dairy manure composed of $60 \%$ separated dairy solids, 30\% sawdust bedded manure, and 10\% straw bedded manure with $2.2 \%$ total nitrogen $(\mathrm{N})$ applied at a rate of $39 \mathrm{Mg} \cdot \mathrm{ha}^{-1}$ of crude compost. Compost was applied to the same subplots each year on 30 Apr. 2007 , 17 Apr. 2008, and 15 Apr. 2009.

FIRST-YEAR ORGANIC PRODUCTION. The main plot factor was organic transition strategy and the subplot factor was compost application. Compost application subplots were divided for production of tomato and potato with weedy and weed-free sub-subplots, which were considered separate experiments superimposed on the transition strategy and compost application study. The experiments for the respective crops constituted a split-splitsplit-plot design. On 15 Apr. 2010, composted dairy manure with the same properties as what was used during transition was applied to the appropriate subplots at the same rate as transition years. The field was disked and seedbed prepared before planting vegetables. A russet type, 'Rio Grande' potato (Ronninger Potato Farm, Austin, CO) was planted on 29 Apr. 2010 , with cut seed tubers of $\approx 35 \mathrm{~g}$ into 5 -ft rows with 1 -ft intrarow spacing at a depth of 4 inches. Seedling of 'Heinz 3402' tomato (Reimer Seeds, Mount Holly, NC), a processing variety, were grown under greenhouse conditions by a commercial grower and mechanically transplanted into flat beds on 27 May 2010 into 5 -ft rows with $1-\mathrm{ft}$ intrarow spacing to give a final population of 24,000 plants/ha. Weeds were controlled in the first organic year with interrow cultivation when weeds were $5 \mathrm{~cm}$ tall and hand hoeing for intrarow control in nonweedy sub-sub-subplots. Weeds were not controlled in the weedy subsub-sub-plots. There was no irrigation applied to plots during the first organic year and no additional management of tomato or potato plants beyond descriptions here.

Data collection. Soil samples were collected on 15 Apr. 2007, before experiment initiation, and on 14 Apr. 2010, before seeding of vegetable crops. Sixteen soil cores per subplot were collected with a diameter of $3 \mathrm{~cm}$ to a depth of $10 \mathrm{~cm}$. Soil samples were amassed for each subplot and dried before analysis. Samples were tested for $\mathrm{pH}$, available $\mathrm{P}$ using a Bray- 1 extractant, exchangeable $\mathrm{K}$, calcium (Ca), and magnesium ( $\mathrm{Mg})$ using an ammonium acetate extractant, and OM using the loss on ignition method.

Weed emergence was counted after planting of potato on 24 May 2010 and tomato on 16 June 2010 from two $0.25-\mathrm{m}^{2}$ quadrants per subplot to determine the effect of transition strategies on weed suppression. Weed biomass was harvested from tomato on 25 Aug. 2010 and potato plots on 15 Sept. 2010 from two $0.5-\mathrm{m}^{2}$ quadrants per subplot to determine the effect of transition strategies and 1 year of organic production on weed suppression. All weed data were collected from the weedy subplots. Weed biomass was separated into canada thistle, monocot, and broadleaf weeds; these were weighed, dried at $55{ }^{\circ} \mathrm{C}$ for $72 \mathrm{~h}$, and weighed again.

Tomatoes were harvested by hand from 5 -ft sections of two rows in each nonweedy subplot between 26 Aug. and 26 Sept. 2010. Harvest times varied by replication because of differences in time to maturity. Tomatoes were separated into marketable composed of ripe fruit meeting standards for categories A and B and nonmarketable composed of fruit that were immature or culls (USDA, 1983). The number and fresh weight of tomatoes in each category were measured. Six marketable tomato fruit from each sub-plot were used for $\mathrm{pH}$ and soluble solids content (SSC) analysis of fruit quality within 24 h of harvest. The six fruit had the pulp removed, flesh was ground in a blender, and a 500-mL sample was stored at $-20^{\circ} \mathrm{C}$ until analysis using digital refractometer (American Optical
10480 Mark II; Reichert, Depew, NY) for SSC and a pH meter (Accument AB15; Fisher Scientific, Pittsburgh) for $\mathrm{pH}$ analysis.

Potatoes were mechanically harvested from 20 - $\mathrm{ft}$ sections of two rows in each nonweedy subplot on 11 Oct. 2010. Potato tubers were graded and classified as U.S. No.1 with diameter of greater than 1.875 inches, U.S. No. 2 with diameter of greater than 1.5 inches, and cull tubers (USDA, 2011). The number and fresh weight of tubers in each category were measured.

Statistical Analysis. Data were analyzed separately by vegetable crop because of differences in dates of planting and data collection. The effects of transition strategy, compost application, and the interaction of transition strategy and compost application on soil $\mathrm{pH}, \mathrm{P}, \mathrm{K}, \mathrm{Ca}, \mathrm{Mg}$, and percent $\mathrm{OM}$ were tested using PROC MIXED in SAS (version 9.2; SAS Institute, Cary, NC) with data from 2007 used as a covariate. Fixed effects were replication, transition strategy, and compost application; random effects were replication by transition strategy interactions. When the interaction of transition strategy and compost application was significant $(P<0.05)$, data were analyzed separately for each transition strategy $\times$ compost application. Means were adjusted for the covariate using the LSMEANS statement in PROC MIXED and means separated using Tukey's test.

The effect of transition strategy, compost application, and the interaction of transition strategy and compost application on weed density and biomass and tomato and potato yield were tested using PROC MIXED. Fixed effects were replication, transition strategy, and compost application; random effects were replication by transition strategy interactions. When the interaction of transition strategy and compost application was significant $(P<0.05)$, data were analyzed separately for each transition strategy $\times$ compost application. Means were determined using the LSMEANS statement and separated using Tukey's test.

\section{Results and discussion}

WEED SUPPRESSION. The interaction of transition strategy and compost application for weed emergence was not significant and data are combined. 
Transition strategies affected density of canada thistle and other broadleaf and monocot weeds in both potato and tomato crop production (Table 1). The most common weed species present were velvetleaf (Abutilon theophrasti), common purslane (Portulaca oleracea), common lambsquarters (Chenopodium album), redroot pigweed (Amaranthus retroflexus), yellow nutsedge (Cyperus esculentus), and large crabgrass (Digitaria sanguinalis). Perennial species used in the prairie transition strategy were not emerged at the time of the measurement of weed density before planting potato or tomato, nor did the prairie species emerge during the growing season as weeds. In potato, the density of canada thistle was lower in the prairie (10 shoots $/ \mathrm{m}^{2}$ ) than the fallow $(38$ shoots $/ \mathrm{m}^{2}$ ) or nontreated strategies $\left(50\right.$ shoots $\left./ \mathrm{m}^{2}\right)$ (Table $\left.\mathrm{l}\right)$. The density of monocot weeds was lower in the prairie transition strategy (200 seedlings $/ \mathrm{m}^{2}$ ) compared with the other treatments, whereas the density of broadleaf weeds was reduced in the prairie strategy (31 seedlings $/ \mathrm{m}^{2}$ ) compared with the fallow (350 seedlings $/ \mathrm{m}^{2}$ ) and vegetable (350 seedlings $/ \mathrm{m}^{2}$ ) strategies (Table 1). Restoration of prairie species has been shown to reduce weed invasions (Blumenthal et al., 2005). The prairie transition strategy included a highly diverse mix of perennial species that occupy multiple ecological niches and give year-round groundcover. The use of species of multiple functional groups may use resources in a complementary manner that facilitates competition with weed species (Liebman and Staver, 2001). Ground cover provided by prairie species may prevent growth and emergence of canada thistle shoots in early spring. Without shoots to produce photosynthetic product, underground storage of root carbohydrates is affected, leading to reduced shoot production (Gustavsson, 1997). In tomato production, canada thistle shoot emergence was reduced in the smother crop transition strategy $(4.3$ shoots $/ \mathrm{m}^{2}$ ) compared with the fallow $\left(28\right.$ shoots $\left./ \mathrm{m}^{2}\right)$ or nontreated $(29$ shoots $/ \mathrm{m}^{2}$ ) (Table $\left.\mathrm{l}\right)$. Smother crops in 2008 and 2009 were planted when canada thistle root carbohydrate reserves were at a seasonal minimum (McAllister and Haderlie, 1985). Canada thistle shoots emerged after

Table 1. Density of canada thistle, monocot, and broadleaf weeds in organic transition strategies and compost applications before planting of potato or tomato in 2010 at Wooster, $\mathrm{OH}$.

\begin{tabular}{|c|c|c|c|c|c|c|}
\hline \multirow[b]{3}{*}{$\begin{array}{l}\text { Transition } \\
\text { strategy }\end{array}$} & \multicolumn{6}{|c|}{ Weed density $\left(\text { no. } / \mathrm{m}^{2}\right)^{\mathrm{z}}$} \\
\hline & \multicolumn{3}{|c|}{ Potato } & \multicolumn{3}{|c|}{ Tomato } \\
\hline & $\begin{array}{c}\text { Canada } \\
\text { thistle }\end{array}$ & Monocots & Broadleaves & $\begin{array}{c}\text { Canada } \\
\text { thistle }\end{array}$ & Monocots & Broadleaves \\
\hline Fallow & $38 a^{y}$ & $570 \mathrm{~b}$ & $350 \mathrm{a}$ & $28 \mathrm{a}$ & $880 \mathrm{a}$ & $640 a$ \\
\hline Nontreated & $50 \mathrm{a}$ & $410 \mathrm{~b}$ & $76 \mathrm{~b}$ & $29 \mathrm{a}$ & $360 \mathrm{~b}$ & $74 \mathrm{~b}$ \\
\hline Prairie & $10 \mathrm{c}$ & $200 \mathrm{c}$ & $31 \mathrm{~b}$ & $16 \mathrm{ab}$ & $190 \mathrm{~b}$ & $45 \mathrm{~b}$ \\
\hline Smother crops & $17 \mathrm{bc}$ & $470 \mathrm{~b}$ & $76 \mathrm{~b}$ & $4.3 \mathrm{~b}$ & $980 \mathrm{a}$ & $64 \mathrm{~b}$ \\
\hline Vegetables & $22 \mathrm{bc}$ & $880 \mathrm{a}$ & $350 \mathrm{a}$ & $18 \mathrm{ab}$ & $980 \mathrm{a}$ & $150 \mathrm{~b}$ \\
\hline$P$ value & 0.03 & 0.0001 & 0.008 & 0.04 & 0.001 & 0.0001 \\
\hline
\end{tabular}

${ }^{\mathrm{z}} 1$ weed $/ \mathrm{m}^{2}=0.0929$ weed $/ \mathrm{ft}^{2}$.

${ }^{y}$ Means within a column and transition strategy or compost application followed by the same letter do not differ according to Tukey's test $(P<0.05)$.

Table 2. Soil $\mathrm{pH}$ and Bray- 1 exchangeable phosphorus $(\mathrm{P})$ as affected by 3 years of organic transition strategies within a compost application in 2010 before planting potato or tomato in 2010.

\begin{tabular}{llc}
\hline Treatment & $\mathrm{pH}$ & $\mathbf{P}\left(\mathbf{m g} \cdot \mathbf{k g}^{-1} \text { soil }\right)^{\mathbf{z}}$ \\
\hline Compost & & \\
$\quad$ Fallow & $7.1 \mathrm{ab}^{\mathrm{y}}$ & $55 \mathrm{a}$ \\
Nontreated & $6.8 \mathrm{c}$ & $40 \mathrm{~b}$ \\
Prairie & $7.0 \mathrm{~b}$ & $42 \mathrm{~b}$ \\
Smother crops & $7.1 \mathrm{ab}$ & $47 \mathrm{~b}$ \\
$\quad$ Vegetables & $7.2 \mathrm{a}$ & $43 \mathrm{~b}$ \\
No compost & & \\
Fallow & $6.9 \mathrm{a}$ & $26 \mathrm{a}$ \\
Nontreated & $6.8 \mathrm{~b}$ & $26 \mathrm{a}$ \\
Prairie & $7.0 \mathrm{a}$ & $28 \mathrm{a}$ \\
Smother crops & $7.1 \mathrm{a}$ & $25 \mathrm{a}$ \\
$\quad$ Vegetables & $6.9 \mathrm{a}$ & $24 \mathrm{a}$ \\
Palues & & \\
TS $\times \mathrm{C}^{\mathrm{x}}$ & 0.03 & 0.05 \\
Covariate & $0.000 \mathrm{l}^{\mathrm{w}}$ & $0.005^{\mathrm{v}}$ \\
\hline
\end{tabular}

${ }^{\mathrm{z}} \mathrm{l} \mathrm{mg} \cdot \mathrm{kg}^{-1}=1 \mathrm{ppm}$.

${ }^{y}$ Means within a column and compost treatment followed by the same letter do not differ according to Tukey's test $(P<0.05)$.

${ }^{\mathrm{x}}$ Transition strategy $\times$ compost application.

${ }^{\mathrm{w}}$ Covariate is soil $\mathrm{pH}$ measured before experiment initiation in 2007.

${ }^{v}$ Covariate is Bray-1 exchangeable P before experiment initiation in 2007.

smother crop planting may not have been able to effectively compete for light and produce carbohydrates for storage, thus affecting the ability of roots to produce shoots.

Weed biomass in potato was affected by the interaction of transition strategy and compost application $(P=0.01)$. In potato, compost application $\left(328 \mathrm{~g} \cdot \mathrm{m}^{-2}\right)$ increased weed biomass compared with the no compost application treatment $\left(257 \mathrm{~g} \cdot \mathrm{m}^{-2}\right)$ $(P=0.007)$. The ranking of transition strategies was different within a compost treatment, but treatments did not differ within compost application (data not shown). In tomato, weed biomass was greater in the compost treatment $\left(240 \mathrm{~g} \cdot \mathrm{m}^{-2}\right)$ than in the no compost treatment $\left(190 \mathrm{~g} \cdot \mathrm{m}^{-2}\right)$ $(P=0.0001)$. The application of plant nutrients through compost likely encouraged weed growth. Weed biomass in tomato was unaffected by transition strategy (data not shown). Weed biomass was harvested after 3 months of tomato growth and 5 months of potato growth. The competition effect of the crop may have reduced any differences between transition strategies.

Although landscape cloth suppressed weeds in the lettuce-brassica crops in 2008, poorly timed rainfall in 2007 and 2009 made timely cultivation in edamame soybeans impossible, resulting in weed seed return and survival of canada thistle roots. The 
density of canada thistle shoots was highest in the nontreated strategy compared with the prairie, smother crop and vegetable treatments in the potato crop (Table 1). Canada thistle was likely able to assimilate and store carbon in underground roots without mechanical management or competition from competitive smother crops or prairie species. The carbohydrate storage may allow canada thistle to produce shoots in subsequent years of organic production, but little is known about the longevity of canada thistle roots (Donald, 1994). Although seed set was prevented in the treatment and the mechanical management would encourage depletion of the seed bank, the strategy did not appear to have long-term effects for weed management once crop production was initiated.

SoIL FERTILITy. Soil $\mathrm{pH}$ and available $\mathrm{P}$ were affected by the interaction of transition strategy and compost application (Table 2). Available $\mathrm{K}, \mathrm{Mg}$, and percent $\mathrm{OM}$ were affected by transition strategy (Table 3). Within the compost treatment, available $\mathrm{P}$ was greater in the fallow transition strategy $\left(55 \mathrm{mg} \cdot \mathrm{kg}^{-1}\right.$ soil $)$ compared with other strategies (Table 2). Available Mg was higher in the prairie transition strategy $\left(200 \mathrm{mg} \cdot \mathrm{kg}^{-1}\right.$ soil) than the vegetable (180 mg $\mathrm{kg}^{-1}$ soil) or fallow treatments (180 $\mathrm{mg} \cdot \mathrm{kg}^{-1}$ soil); and percent $\mathrm{OM}$ was higher in the prairie transition strategy than the fallow $(2.8 \%)$, smother crop $(2.9 \%)$, and vegetable $(2.7 \%)$ treatments (Table 3 ). In the prairie and nontreated transition strategies, $\mathrm{K}, \mathrm{Mg}$, and percent $\mathrm{OM}$ were not different where the soil was not disturbed during the 3-year transition phase (Table 3 ). Soil disturbance results in loss of nutrients and OM from soil and tillage practices within a transition strategy contributed to differences in soil fertility after 3 years. However, changes in soil nutrients and $\mathrm{OM}$ in studies comparing the effects of soil tillage often take more than 3 years to accumulate (Pekrun et al., 2003). The similarities in soil properties between transition strategies, especially the nontreated and prairie strategies, can also be the result of the length of this study.

Compost application affected available $\mathrm{K}, \mathrm{Ca}$, and $\mathrm{Mg}$, and percent OM (Table 3 ). The addition of soil nutrients and $\mathrm{OM}$ in the compost would be expected to increase soil fertility during the transition years without depletion by vegetation or soil disturbance. Soil nutrients K and $\mathrm{Mg}$ were generally lowest in the

vegetable transition strategy (Table 3 ). The vegetable crops planted would use some of the available soil nutrients for growth and development. The use

Table 3. Exchangeable potassium (K), calcium (Ca), and magnesium (Mg), and percent organic matter $(\mathrm{OM})$ in soil as affected by 3 years of organic transition strategies and compost application in 2010 before planting potato and tomato.

\begin{tabular}{lcccc}
\hline & $\mathbf{K}$ & $\begin{array}{c}\mathbf{C a} \\
\left(\mathbf{m g} \cdot \mathbf{k g}^{-1} \text { soil }\right)^{\mathbf{z}}\end{array}$ & $\mathbf{M g}$ & OM (\%) \\
\hline Transition strategy & & & & \\
$\quad$ Fallow & $280 \mathrm{a}^{\mathrm{y}}$ & $1300 \mathrm{a}$ & $180 \mathrm{~b}$ & $2.8 \mathrm{~b}$ \\
$\quad$ Nontreated & $250 \mathrm{a}$ & $1300 \mathrm{a}$ & $190 \mathrm{a}$ & $3.1 \mathrm{a}$ \\
Prairie & $260 \mathrm{a}$ & $1300 \mathrm{a}$ & $200 \mathrm{a}$ & $3.2 \mathrm{a}$ \\
Smother crops & $260 \mathrm{a}$ & $1400 \mathrm{a}$ & $190 \mathrm{a}$ & $2.9 \mathrm{~b}$ \\
$\quad$ Vegetables & $190 \mathrm{~b}$ & $1300 \mathrm{a}$ & $180 \mathrm{~b}$ & $2.7 \mathrm{~b}$ \\
$\begin{array}{l}\text { Palue } \\
\text { Compost application }\end{array}$ & 0.004 & 0.39 & 0.003 & 0.0007 \\
$\quad$ & & & \\
$\quad$ Compost & $360 \mathrm{a}$ & $1400 \mathrm{a}$ & $200 \mathrm{a}$ & $3.4 \mathrm{a}$ \\
$\quad$ No compost & $140 \mathrm{~b}$ & $1200 \mathrm{~b}$ & $170 \mathrm{~b}$ & $2.5 \mathrm{~b}$ \\
Pvalue & 0.0001 & 0.0001 & 0.0001 & 0.0001 \\
Covariate & $0.34^{\mathrm{x}}$ & $0.01^{\mathrm{w}}$ & $0.008^{\mathrm{v}}$ & $0.007^{\mathrm{u}}$ \\
\hline
\end{tabular}

${ }^{\mathrm{z}} \mathrm{l} \mathrm{mg} \cdot \mathrm{kg}^{-1}=1 \mathrm{ppm}$.

${ }^{y}$ Means within a column and transition strategy or compost application followed by the same letter do not differ according to Tukey's test $(P<0.05)$.

${ }^{\mathrm{x}}$ Covariate is exchangeable $\mathrm{K}$ before experiment initiation in 2007.

"Covariate is exchangeable Ca before experiment initiation in 2007

${ }^{v}$ Covariate is exchangeable $\mathrm{Mg}$ before experiment initiation in 2007.

"Covariate is percent OM before experiment initiation in 2007.
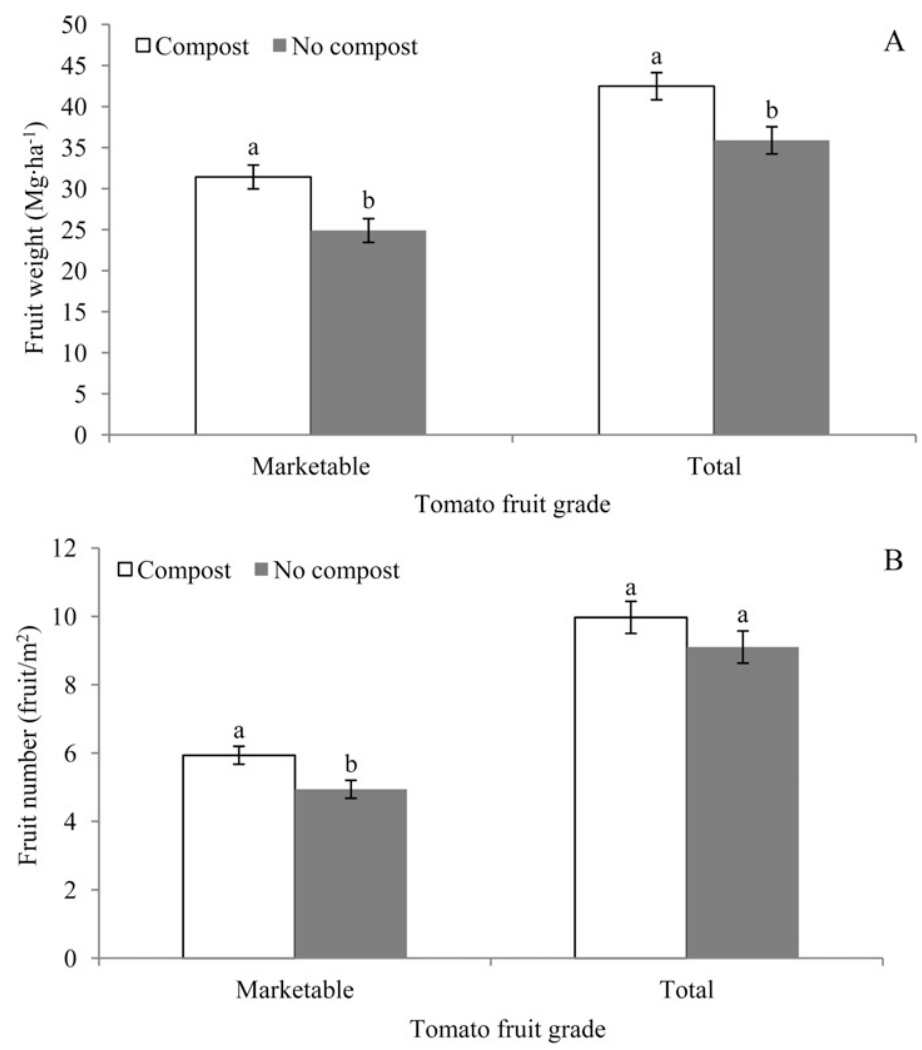

Fig. 1. The total and marketable weight (A) and number (B) of processing type 'Heinz 3402' tomato fruit as affected by compost treatment with plant density of 25,000 plants/ha $(10,117.1$ plants/acre $)$ in 2010 at Wooster, $\mathrm{OH}$. Bars within a group with the same letter do not differ according to Tukey's test $(P<0.05)$; $1 \mathrm{Mg} \cdot \mathrm{ha}^{-1}=0.4461$ ton $/$ acre, 1 fruit $/ \mathrm{m}^{2}=0.0929$ fruit $/ \mathrm{ft}^{2}$. 
of annual vegetable crops in the vegetable strategy may also slow the accumulation of OM compared with other transition strategies (Table 3 ). Harvesting of aboveground plant biomass removed a source of organic carbon (OC) for soil, and annual root systems may contribute less to soil OC pools in comparison with perennial root systems (Kögel-Knabner, 2002). Strategies that included cultivation, such as the fallow, smother crops, and vegetables, had lower percent OM than treatments without soil disturbance (Table 3). Soil disturbance through tillage and cultivation in these strategies may decrease the rate of soil OM build-up (Jackson et al., 2004).

Tomato AND POTATO YIELD. Tomato (Fig. 1) marketable yield was affected by compost application. Tomato fruit quality as measured by $\mathrm{pH}$ and SSC were unaffected by transition strategy or compost application (data not shown). The weight of marketable tomato fruit was greater with compost application (31.4 Mg.ha' compared with the no compost treatment (24.9 Mg.ha $\left.{ }^{-1}\right)$ (Fig. 1A). The total number of tomato fruit did not differ between compost (10.0 fruit/ $\mathrm{m}^{2}$ ) and the no compost treatments (9.1 fruit $/ \mathrm{m}^{2}$ ) (Fig. 1B). Although the total number of fruit was unaffected by compost treatment, number of marketable fruit (compost $=5.9$ fruit $/ \mathrm{m}^{2}$, no compost $=4.9$ fruit $/ \mathrm{m}^{2}$ ) was affected by compost treatment (Fig. 1B). The addition of soil nutrients through compost application did not affect the total number of fruit, but may have affected fruit shape and susceptibility to pests.

Compost application increased the number of marketable potato tubers $\left(\right.$ compost $=2.2$ tubers $/ \mathrm{m}^{2}$; no compost $=1.3$ tubers $\left./ \mathrm{m}^{2}\right)($ Fig. $2 \mathrm{~B})$ and the weight of marketable tubers $\left(\right.$ compost $=16 \mathrm{Mg} \cdot \mathrm{ha}^{-1}$; no compost $=$ 7.8 $\mathrm{Mg} \cdot \mathrm{ha}^{-1}$ ) (Fig. 2A). The application of compost increased yield through the supply of plant available and potentially mineralizable nutrients. Transition strategy did not affect the number $(P=0.56)$ or weight $(P=$ 0.49 ) of marketable tomato fruit; or the number $(P=0.11)$ or weight $(P=$ $0.11)$ of marketable potato tubers. Since cultivation and hoeing were used for weed control during the first organic year in the weed-free subplots, the effect of the changes in weed populations as a result of transition
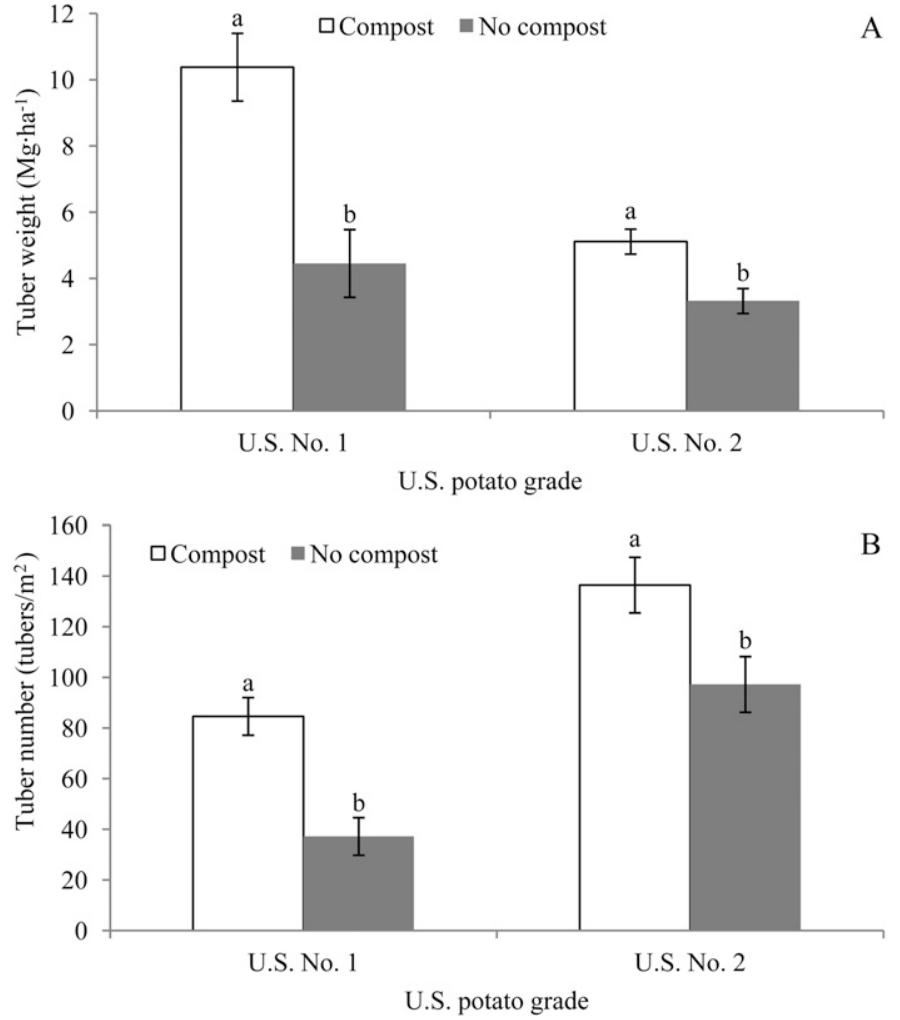

Fig. 2. The weight (A) and number (B) of U.S. No. 1 (diameter $>1.875$ inch) and No. 2 (diameter $>1.5 \mathrm{inch}$ ) russet-type 'Rio Grande' potato tubers as affected by compost treatment with plant density of 1400 plants/ha (566.6 plants/acre) in 2010 at Wooster, $\mathrm{OH}$. Bars within a group with the same letter do not differ according to Tukey's test $(P<0.05) ; 1 \mathrm{Mg} \cdot \mathrm{ha}^{-1}=0.4461$ ton $/$ acre, $1 \mathrm{tuber} / \mathrm{m}^{2}=$ 0.0929 tuber $/ \mathrm{ft}^{2}, 1$ inch $=2.54 \mathrm{~cm}$.

strategy may not be observed in vegetable yield data (Table 1). However, the effect of transition strategy on number $(P=0.0006)$ and weight $(P=$ $0.0005)$ of cull potato tubers was significant (Fig. 3). There were more cull potato tubers, and the weight of cull tubers was greater in the nontreated strategy (number $=6.6$ tubers $\mathrm{m}^{2}$; weight $=5.1 \mathrm{Mg} \cdot \mathrm{ha}^{-1}$ ) compared with the smother crop (number $=1.9$ tubers $/ \mathrm{m}^{2}$; weight $\left.=0.61 \mathrm{Mg} \cdot \mathrm{ha}^{-1}\right)$ or vegetable strategy (number $=1.8 \mathrm{tu}-$ bers $/ \mathrm{m}^{2}$; weight $\left.=0.40 \mathrm{Mg} \cdot \mathrm{ha}^{-1}\right)(\mathrm{Fig}$. $3)$. The nontreated and prairie transition strategies had the least amount of soil disturbance over the 3 years of transition compared with the other treatments. Soil physical properties as affected by tillage can influence potato yield (Pierce and Burpee, 1995). Soil disturbance in the fallow, smother crops, and vegetable strategies may have affected the quantity of cull potato tubers.

The transition strategy implemented during the 3 years before organic farming can affect weed density in the first year of organic production. The use of native, perennial prairie species can provide suppression of canada thistle, monocot, and broadleaf weeds. Prairie species also represent a potential source of biofuel feedstocks for burgeoning lignocellulosic fuel markets that may provide economic return during transition (Jefferson et al., 2004; Tilman et al., 2006). Future success and adoption of the prairie transition strategy depends upon further development of lignocellulosic biofuel conversion processes and markets. Smother crops are also effective at reducing emergence of canada thistle in comparison with the nontreated strategy before tomato and potato production. To improve economic return for farmers while suppressing canada thistle, the smother cropping strategy could be used in rotation with short-season vegetable crops such as lettuce or smother crops could be chosen for use as forages or hay.

To improve economic return during the transition period to organic production, the second year phase of 

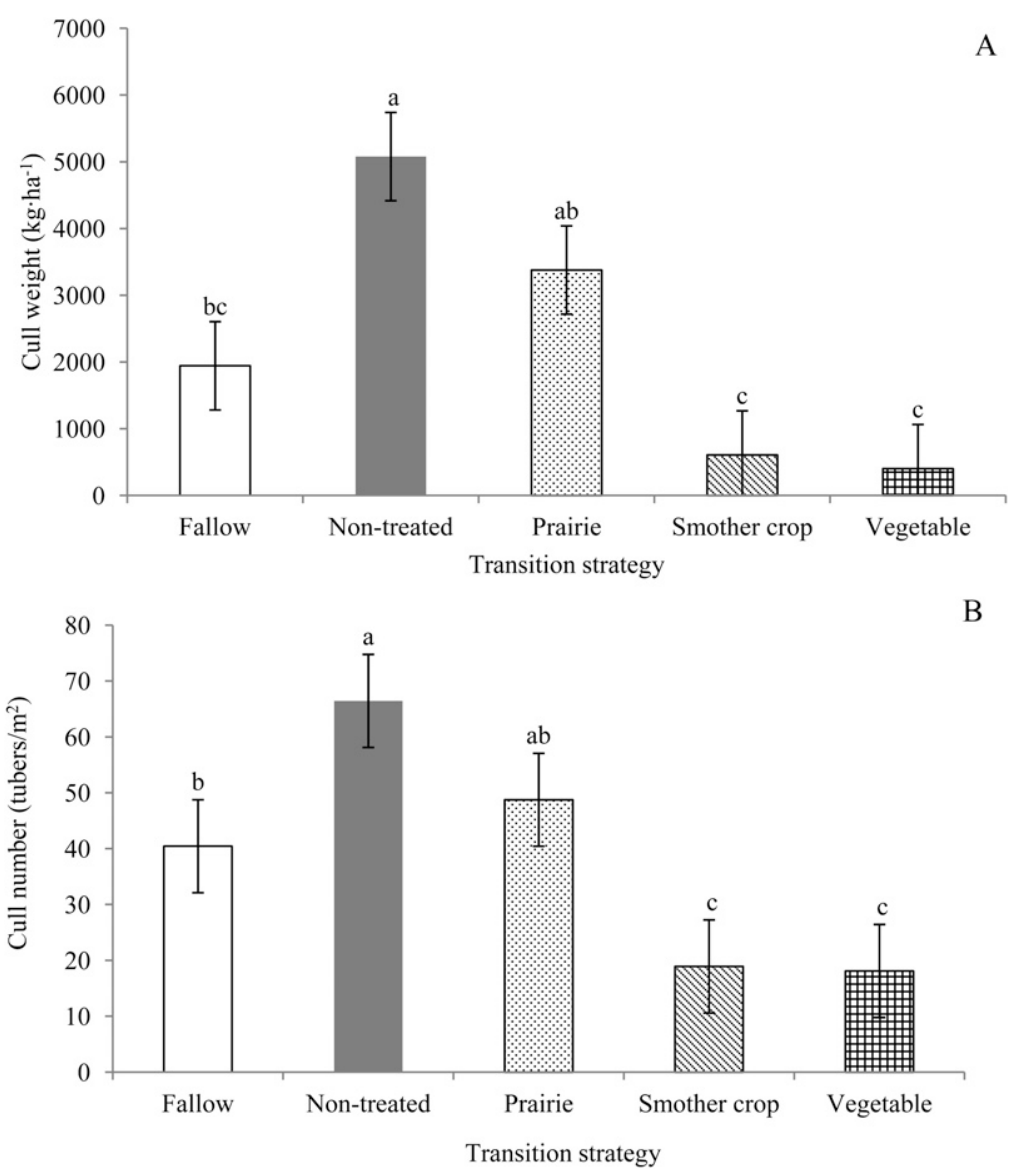

Fig. 3. The weight (A) and number (B) of cull russet type 'Rio Grande' potato tubers as affected by organic transition strategy with plant density of 1400 plants/ha (566.6 plants/acre). Bars within a group with the same letter do not differ according to Tukey's test $(P<0.05) ; 1 \mathrm{~kg} \cdot \mathrm{ha}^{-1}=0.8922 \mathrm{lb} / \mathrm{acre}, 1 \mathrm{tuber} / \mathrm{m}^{2}=$ 0.0929 fruit $/ \mathrm{ft}^{2}$.

the vegetable transition strategy could be practiced for all 3 years of the transition. This approach would allow farmers to realize profit from growing annual vegetable crops while preventing the growth and reproduction of weeds with black landscape cloth and improving soil fertility with compost application. Compost applications and transition strategies during organic transition improved soil fertility and potato and tomato yield during the first year of organic production. Transition strategies that increase soil nutrients in combination with compost applications can be most effective in improving yields in the first year of organic vegetable production. However, strategies that cannot be adapted for economic return may not serve to remove the barriers to transitioning to organic production.

The objective of this study was to evaluate cropping and management systems for transition to organic agriculture and evaluate the effect of those systems on the first year of organic production. This is the minimum period of time for transition experiments as productivity in organic systems usually improves with increasing years in organic management (Delate and Cambardella, 2004). The first year of organic production is crucial to establish the success or failure of transition strategies for weed management and improvement of soil fertility. Including additional years of organic production beyond the first organic year changes the scope of the study and the influence of transition strategies. To remove the barriers farmers perceive in converting to organic management, assessment of the products that can be sold at the premium organic prices is crucial to ensure that farmers know the impact of transition strategies on potential economic return. However, further research could consider integration of systems that are effective in managing biotic and abiotic factors as well as providing financial return if economic considerations are also a barrier. Further research may consider the effect of novel cropping strategies on a wider variety of organic crops and other measures of soil quality such as microbial communities and physical properties. Although strategies without economic return may not be appealing to farmers for short-term benefits, understanding the long-term implications of transition strategies for weed management, soil fertility, and yields once organic premium prices are realized can improve management decisions in organic production.

\section{Literature cited}

Baysal, F., M. Benitez, M.D. Kleinhenz, S.A. Miller, and B.B. McSpadden Gardener. 2008. Field management effect on damping-off and early season vigor of crops in a transitional organic cropping system. Phytopathology 98:562-570.

Beveridge, L.E. and R.E.L. Naylor. 1999. Options for organic weed control - What farmers do. 1999 Brighton Crop Protection Conference-Weeds. British Crop Protection Council, Brighton, United Kingdom. p. 939-944.

Blumenthal, D.M., N.R. Jordan, and E.L. Svenson. 2005. Effects of prairie restoration on weed invasions. Agr. Ecosyst. Environ. 107:221-230.

Briar, S.S., S.A. Miller, D. Stinner, M.D. Kleinhenz, and P.S. Grewal. 2011. Effects of organic transition strategies for periurban vegetable production on soil properties, nematode community, and tomato yield. Appl. Soil Ecol. 47:84-91.

Corbin, A.T., K.D. Thelen, G.P. Robertson, and R.H. Leep. 2010. Influence of cropping systems on soil aggregate and weed seedbank dynamics during the organic transition period. Agron. J. 102:1632-1640.

Delate, K. and C.A. Cambardella. 2004. Agroecosystem performance during transition to certified organic grain production. Agron. J. 96:1288-1298.

Donald, W.W. 1994. The biology of canada thistle (Cirsium arvense). Rev. Weed Sci. 6:77-101.

Dorais, M. 2007. Organic production of vegetables: State of the art and challenges. Can. J. Plant Sci. 87:1055-1066.

Gustavsson, A.M.D. 1997. Growth and regenerative capacity of plants of Cirsium arvense. Weed Res. 37:229-236. 
Hanson, J., R. Dismukes, W. Chambers, C. Greene, and A. Kremen. 2004. Risk and risk management in organic agriculture: Views of organic farmers. Renewable Agr. Food Systems 19:218-227.

Jackson, L.E., I. Ramirez, R. Yokota, S.A. Fennimore, S.T. Koike, D.M. Henderson, W.E. Chaney, F.J. Calderón, and K. Klonsky. 2004. On-farm assessment of organic matter and tillage management on vegetable yield, soil, weeds, pests, and economics in California. Agr. Ecosyst. Environ. 103: $443-463$.

Jefferson, P.G., W.P. McCaughey, K. May, J. Woosaree, and L. McFarlane. 2004. Potential utilization of native prairie grasses from western canada as ethanol feedstock. Can. J. Plant Sci. 84:1067-1075.

Kögel-Knabner, I. 2002. The macromolecular organic composition of plant and microbial residues as inputs to soil organic matter. Soil Biol. Biochem. 34:139-162.

Larkin, R.P., C.W. Honeycutt, T.S. Griffin, O.M. Olanya, J.M. Halloran, and Z. He. 2011. Effects of different potato cropping system approaches and water management on soilborne diseases and soil microbial communities. Phytopathology 101:58-67.

Liebman, M. and C.P. Staver. 2001. Crop diversification for weed management, $\mathrm{p}$. 322-374 In: M. Liebman, C.L. Mohler, and C.P. Staver (eds.). Ecological management of agricultural weeds. Cambridge University Press, Cambridge, United Kingdom.

Martini, E.A., J.S. Buyer, D.C. Bryant, T.K. Hartz, and R.F. Denison. 2004.
Yield increases during the organic transition: Improving soil quality or increasing experience? Field Crops Res. 86:255-266.

McAllister, R.S. and L.C. Haderlie. 1985. Seasonal variations in canada thistle ( $\mathrm{Cir}$ sium arvense) root bud growth and root carbohydrate reserves. Weed Sci. 33:4449.

Oberholtzer, L., C. Dimitri, and C. Greene. 2005. Price premiums hold on as U.S. organic produce market expands. U.S. Dept. Agr., Econ. Res. Serv., Resources Econ. Div., VGS- 308-01.

Pekrun, C., H-P. Kaul, and W. Claupein. 2003. Soil tillage for sustainable nutrient management, p. 83-113 In: A.E. Titi (ed.). Soil tillage in agroecosystems CRC Press, Boca Raton, FL.

Pierce, F.J. and C.G. Burpee. 1995. Zone tillage effects on soil properties and yield and quality of potatoes (Solanum tuberosum L.). Soil Tillage Res. 35:135-146.

Russo, V.M. and M. Taylor. 2006. Soil amendments in transition to organic vegetable production with comparison to conventional methods: Yields and economics. HortScience 41:1576-1583.

Smith, R.G., M.E. Barbercheck, D.A Mortensen, J. Hyde, and A.G. Hulting. 2011. Yield and net returns during the transition to organic feed grain production. Agron. J. 103:51-59.

Smukler, S.M., L.E. Jackson, L. Murphree, R. Yokota, S.T. Koike, and R.F. Smith. 2008. Transition to large-scale organic vegetable production in the Salinas Valley,
California. Agr. Ecosyst. Environ. 126: 168-188.

Tilman, D., J. Hill, and C. Lehman. 2006. Carbon-negative biofuels from low-input high- diversity grassland biomass. Science 314:1598-1600.

Turner, R.J., G. Davies, H. Moore, A.C. Grundy, and A. Mead. 2007. Organic weed management: A review of the current UK farmer perspective. Crop Protection 26:377-382.

U.S. Department of Agriculture. 1983. United States standards for grades of tomatoes for processing. U.S. Dept. Agr., Agr. Mktg. Serv., Fruit and Veg. Programs, Fresh Prod. Branch., Washington, DC.

U.S. Department of Agriculture. 2010. Organic Production. 16 Aug. 2011. <http:// www.ers.usda.gov/Data/Organic/>.

U.S. Department of Agriculture. 2011. United States standards for grades of potatoes. U.S. Dept. Agr., Agr. Mktg. Serv., Fruit Veg. Programs, Fresh Prod. Branch, Washington, DC.

Verschwele, A. and A. Häusler. 2004. Effect of crop rotation and tillage on infestation of Cirsium arvense in organic farming systems. Proc. 6th EWRS Workshop on Physical and Cultural Weed Control. European Weed Res. Soc., Lillehammer, Norway. p. 187194. 